\title{
Systematically transplanted human gingiva-derived mesenchymal stem cells regulate lipid metabolism and inflammation in hyperlipidemic mice with periodontitis
}

\author{
XIAOXUAN LIU ${ }^{1,2}$, ZHIGUO WANG ${ }^{3}$, WENBIN SONG ${ }^{1}$, WENDONG SUN ${ }^{1}$, \\ RUNDAN HONG ${ }^{1}$, ANITA POTHUKUCHI ${ }^{4}$ and QUANCHEN XU ${ }^{1}$
}

\begin{abstract}
${ }^{1}$ Department of Stomatology, Dental Digital Medicine and 3D Printing Engineering Laboratory of Qingdao University, The Affiliated Hospital of Qingdao University, Qingdao, Shandong 266003; ${ }^{2}$ Department of Stomatology, Yidu Central Hospital of Weifang, Weifang, Shandong 262500; ${ }^{3}$ Department of Burn and Plastic Surgery, The Affiliated Hospital of Qingdao University, Qingdao, Shandong 266003, P.R. China; ${ }^{4}$ Department of Physical and Biological Sciences, University of California, Santa Cruz, CA 95064, USA
\end{abstract}

Received October 21, 2018; Accepted November 7, 2019

DOI: $10.3892 /$ etm.2019.8256

\begin{abstract}
Gingiva-derived mesenchymal stem cells (GMSCs) have been the focus of extensive research due to their numerous distinct properties, including their homing to injury sites and their contribution to tissue regeneration. However, the role of transplanted GMSCs in the regulation of lipid metabolism and inflammation in hyperlipidemic mice with periodontitis has not been demonstrated. In the present study, apolipoprotein E-deficient $\left(\mathrm{ApoE}^{-/}\right)$mice were used to establish a hyperlipidemia model with periodontitis and divided into two groups: Group B and Group C ( $\mathrm{n}=20$ per group), and wild-type $\mathrm{C} 57 \mathrm{BL} / 6 \mathrm{~J}$ mice without any treatment were assigned to Group A ( $n=20)$. Animals in Group C were then injected with human GMSCs through the tail vein and animals in Group B were injected with $\alpha$-MEM as control. Animals were sacrificed at indicated time points. Serum was collected to determine the lipids and inflammatory cytokines. Liver samples were collected to estimate lipid-associated gene expression. Morphometric and histological analyses were performed to maxillaries. The results demonstrated that the delivery of GMSCs led to a significant decrease in triglyceride (TG), total cholesterol (TC), low density lipoprotein cholesterol (LDL), interleukin (IL)-6, tumor necrosis factor (TNF)- $\alpha$, alveolar bone loss (ABL), and sterol regulatory element binding protein-1c (SREBP-1c) mRNA, and a significant increase in high density lipoprotein cholesterol (HDL), IL-10
\end{abstract}

Correspondence to: Dr Quanchen Xu, Department of Stomatology, Dental Digital Medicine and 3D Printing Engineering Laboratory of Qingdao University, The Affiliated Hospital of Qingdao University, 16 Jiangsu Road, Qingdao, Shandong 266003, P.R. China

E-mail: qyfyxqc@126.com

Key words: gingiva, mesenchymal stem cells, systematical transplantation, hyperlipidemia, periodontitis and peroxisome proliferator-activated receptor $\alpha$ (PPAR $\alpha)$ mRNA in Group C compared to Group B. Histological examination showed increased formation of new bone and higher alveolar bone height in Group C. Systematically transplanted GFP-positive cells were detected through both fluorescence microscope observation and immunohistochemical staining in the periodontal tissues. Overall, systematically transplanted GMSCs attenuated the hyperlipidemia and inflammatory responses in hyperlipidemic mice with periodontitis, and improved periodontal tissue regeneration.

\section{Introduction}

Periodontitis is an inflammatory disease caused by specific microorganisms and their products are main pathogens, characterized by progressive periodontal ligaments and proximal alveolar bone damage and a final loss of teeth (1). Periodontal diseases have been recognized as potential risk factors for many systemic diseases, such as diabetes mellitus and cardiovascular diseases (2). Hyperlipidemia, one of the modern concerns of society, generates increasingly adverse effects on general health. Increased emphasis has been placed on the influence of hyperlipidemia on general inflammation and cardiovascular disease, especially atherosclerosis (3).

A relationship between hyperlipidemia and periodontitis has been noted in recent years (4-7). Numerous animal experiments have further illustrated the existence of the bi-directional relationship between hyperlipidemia and periodontitis $(8,9)$. The vicious circle formed between inflammation and lipid metabolism is considered to be the pathological basis between periodontitis and hyperlipidemia. On one hand, inflammation leads to abnormal blood lipid metabolism; periodontal pathogenic bacteria and their metabolites and pro-inflammatory cytokines from periodontal infection cause lipid metabolism disorder, lipid peroxidation, and elevated blood lipid levels, which promote the formation of hyperlipidemia (10). On the other hand, elevated blood lipid levels and lipid peroxidation lead to disorders of immune regulation, stimulate the 
expression of pro-inflammatory cytokines, cause oxidative stress, delay wound healing, and increase the body's susceptibility to periodontitis $(11,12)$.

In recent years, gingival mesenchymal stem cells (GMSCs) have been found to possess properties of mesenchymal stem cells (MSCs), including self-renewal, clonogenicity, multi-differentiation, and expression of MSC-associated surface markers (13). As newly discovered MSCs, GMSCs have received increased attention due to their various distinct properties: Accessible tissue source, ease of isolation, uniformly homogenous property, rapid proliferation capacity, stable morphology, and ability to maintain the characteristics of MSCs over long-term culture time $(14,15)$. Local transplantation of GFP-labeled GMSC sheets in a dog model with class III furcation defects was found to significantly increase periodontal regeneration (16). In our previous study, we demonstrated that GFP-labeled GMSCs transplanted by tail vein into mice with mandibular bone defects could home to the defect sites and accelerate bone regeneration (17).

In contrast to other MSCs, GMSCs displayed more powerful anti-inflammatory and immunomodulatory functions. Recent experimental studies have reported that GMSCs suppress T-lymphocyte proliferation and activation, and possess powerful immunomodulatory function on several innate immune cells, particularly macrophages, mast cells, and dendritic cells $(14,18)$. The immunomodulatory properties of GMSCs have been applied in the therapy of a few inflammatory-related diseases in animal models, including immunological rejection, contact hypersensitivity, and experimental colitis. Furthermore, these properties exhibited unique advantages compared to other seed cells such as bone marrow-derived stem cells (BMSCs) and periodontal ligament-derived stem cells (PDLSCs) (19-21). Our previous study demonstrated that hyperlipidemia can reduce homing efficiency of systemically transplanted BMSCs and suppress bone regeneration (22). To date, however, the regulatory effect of systematically transplanted GMSCs on lipid metabolism and periodontal inflammation has not been reported. As a recent report demonstrated, systematically transplanted BMSCs possess the capacity to attenuate serum lipid profile, blood glucose, and oxidative stress in rats with diabetes (19). As such, we speculated that GMSCs can rectify lipid metabolism disorders and reduce inflammation, therefore contributing to periodontal tissue reconstruction. In the present study, we transplanted human GMSCs into experimental hyperlipidemic mice with periodontitis via the tail vein to explore the role of GMSCs in the regulation of lipid metabolism and inflammation.

\section{Materials and methods}

Isolation, culture and characterization of GMSCs. Human gingiva samples were extracted from discarded tissues from healthy volunteers (18-25 years of age), who underwent routine dental procedures at the Department of Stomatology, Affiliated Hospital of Qingdao University. All procedures were approved by the Clinical Research Ethics Committee of Qingdao University (Qingdao, China) with informed consent provided by the participants. The gingival tissues were washed several times with PBS, containing $400 \mu \mathrm{g} / \mathrm{ml}$ streptomycin and $400 \mathrm{U} / \mathrm{ml}$ penicillin. The tissues were then incubated overnight with $\alpha$-MEM (Hyclone; GE Healthcare) which contained $2 \mathrm{mg} / \mathrm{ml}$ dispase II (Sigma-Aldrich; Merck $\mathrm{KGaA})$ at $4^{\circ} \mathrm{C}$. Following separation of the epithelial layer, the connective tissue was minced into fragments and digested with $2 \mathrm{mg} / \mathrm{ml}$ collagenase I (Sigma-Aldrich; Merck KGaA) at $37^{\circ} \mathrm{C}$ for $40 \mathrm{~min}$. The tissue explants were placed into $25 \mathrm{~mm}^{2}$ culture flask containing $\alpha$-MEM medium with $15 \%$ FBS (Hyclone; GE Healthcare) at $37^{\circ} \mathrm{C}$ in $5 \% \mathrm{CO}_{2}$. The second to fourth generation cells were used for further experiments.

A colony-forming unit-fibroblast (CFU-F) assay was conducted to determine the colony forming efficiency of the GMSCs. Adipogenic and osteogenic differentiation were performed to determine the multipotent differentiation trait of the GMSCs. GMSCs $\left(1 \times 10^{6}\right)$ at passage 4 were collected and washed twice with PBS, and then the cells were incubated with antibodies against human CD73 (1:20; cat. no. 344015; BioLegend, Inc.), CD90 (1:20; cat. no. 328107; BioLegend, Inc.), CD105 (1:20; cat. no. 323205; Biolegend, USA), STRO-1 (1:100; cat. no. 398401; eBioscience; Thermo Fisher Scientific, Inc.), CD45 (1:20; cat. no. 368507; BioLegend, Inc.) and CD31 (1:20; cat. no. 303103; BioLegend, Inc.) for flow cytometry analysis with the use of a flow cytometer (Beckman Coulter) (17,23).

Green fluorescent protein (GFP) transfection of GMSCs. Lentiviral vectors with GFP (Genechem) were used to label GMSCs to trace the fate of the GMSCs in the mice. First-passage GMSCs $\left(2 \times 10^{3}\right.$ cells/well) were seeded in 6-well plates for $24 \mathrm{~h}$. Then, the culture medium was replaced with the virus solution diluted by serum-free $\alpha$-MEM $(50 \mu \mathrm{g} / \mathrm{ml})$. The viral solution was replaced with complete culture medium after being transfected for $8 \mathrm{~h}$. The GFP ${ }^{+}$GMSCs were expanded and cells from third to fifth passage were transplanted into the mice.

Establishment of the experimental hyperlipidemia model with periodontitis in mice. Male, 8 -week-old $\mathrm{ApoE}^{-/}$mice with a C57BL/6J background and wild-type C57BL/6J mice (total number of mice: 60 ; weight, $20.59 \pm 1.42 \mathrm{~g}$; Peking University Health Science Center) were all fed a cholate/high-cholesterol/high-fat diet $(0.5 \% / 1.25 \% / 15 \%$, respectively) throughout the experiments. Animals were maintained under a temperature controlled $\left(24 \pm 1.0^{\circ} \mathrm{C}\right)$ environment with a 12 -h dark/light cycle and fed a high fat diet (HFD) and aseptic water ad libitum. This study was consistent with the Institutional Review Board and the Ethics Committee of the Affiliated Hospital of Qingdao University (approval no. QYFYKYLL-2017-01-2).

After 4 weeks of HFD, a 5-0 silk ligature was placed on the maxillary second molars $(\mathrm{mxM} 2)$ of the $\mathrm{ApoE}^{-/}$mice for 4 weeks. ApoE ${ }^{-/}$mice were divided into two groups, Group B and Group $C$ ( $n=20$ per group), while wild-type C57BL/6J mice without any treatment were assigned to Group A $(n=20)$. To confirm the establishment of periodontitis, 2 mice in every group were sacrificed and the maxillary bones were removed and treated using the following procedure.

The isolated samples were boiled for 10 min under a bar pressure to remove soft tissue and then soaked in a hydrogen peroxide solution for $12 \mathrm{~h}$. Afterwards, the samples were stained with methylene blue and washed with PBS. Images were captured using a stereomicroscope (Olympus Corporation) at x200 magnification and assessed with Image-Pro-Plus 6.0 
software program (Media Cybernetics, Inc.). Alveolar bone loss was determined as the sum of distances from the alveolar bone crest $(\mathrm{ABC})$ to the cementoenamel junction (CEJ) at 12 sites as previously described (24): 4 sites for $\mathrm{mxM1}$ (disto-buccal groove and disto-palatal groove, buccal of distal cusp and palatal of distal cusp); 6 sites for mxM2 (mesio-buccal cusp and mesio-palatal cusp, buccal groove and palatal groove, disto-buccal cusp and disto-palatal cusp) and 2 sites for mxM3 (buccal cusp and palatal cusp).

GMSC transplantation. After 4 weeks of ligation on mxM2, the suture was removed, followed by GMSC transplantation. Briefly, Group C was administered $500 \mu 1 \alpha$-MEM containing $1 \times 10^{6}$ GMSCs; Group B was injected with $500 \mu 1 \alpha$-MEM as control. Mice were anesthetized using $1.5 \%$ pentobarbital and sacrificed with carbon dioxide at 1,2 and 4 weeks after transplantation (Fig. 1).

Blood sample preparation and reverse transcription-polymerase chain reaction (RT-PCR) of liver tissues. Blood samples were obtained from the angular vein at $0,4,8,9,10$ and 12 weeks after HFD to test serum lipid levels, including triglyceride (TG), total cholesterol (TC), low density lipoprotein cholesterol (LDL) and high density lipoprotein cholesterol (HDL) using an autoanalyzer (Hitachi). The serum levels of interleukin (IL)-6, tumor necrosis factor (TNF)- $\alpha$ and IL-10 were determined by ELISA kits (Elabscience), according to the protocol of the manufacturer.

TRIzol reagent (Takara) was used to extract the RNA from liver tissues on the basis of the protocol of the manufacturer. High-capacity cDNA reverse transcription kits (Takara) were used to synthesize the complementary DNA in accordance with the protocol of the manufacturer. cDNA was then subjected to quantitative real-time PCR amplification using PowerUp ${ }^{\mathrm{TM}}$ SYBR Green Master Mix (Takara). Reactions were run on a LightCycler 480 Real-Time PCR System (Roche Applied Science). Relative mRNA expression of the peroxisome proliferator-activated receptor $\alpha(P P A R \alpha)$ and sterol regulatory element binding protein-1c (SREBP-1c) genes was calculated by the $2^{-\triangle \Delta C q}(25)$ method and normalized to the gene GAPDH as an internal control. The forward and reverse primers are listed in Table I.

Morphometric and histologic analyses. The left maxillaries were stained with methylene blue using the same methods as described above in the section (establishment of experimental hyperlipidemia model with periodontitis in mice.). The right maxillaries were isolated after perfusion fixation with $4 \%$ paraformaldehyde. The tissue was demineralized in 10\% EDTA for 4 weeks and then embedded in paraffin. Tissue sections, $5-\mu \mathrm{m}$ thick, were cut in the mesial-distal direction. Sections of the most central areas of the second molars were selected, for which two sections were stained with hematoxylin and eosin (H\&E) and Masson Trichrome (MT) staining. Images were captured under a light microscope at x100 magnification (Olympus Corporation).

Fluorescence microscope observation and immunohistochemical staining for GFP. To trace the fate of GMSCs in mice with periodontitis, fluorescence microscope observation and immunohistochemical staining were performed. The rehydrated sections were washed with PBS for 5 min and stained with DAPI for $5 \mathrm{~min}$. The slices were observed under a fluorescence microscope (Olympus Corporation) at $\mathrm{x} 400$ magnification after being washed with PBS.

Immunohistochemical study was performed using a rabbit antibody (GFP; 1:100; cat. no. AB183734; Abcam) against GFP. Sections were treated with $3 \% \mathrm{H}_{2} \mathrm{O}_{2}$ for 10 min to block peroxidase after being dewaxed and hydrated. Then, the sections were incubated with the primary antibody at $37^{\circ} \mathrm{C}$ for $90 \mathrm{~min}$, washed with PBS, and incubated with anti-rabbit secondary antibody (PV-6001; 1:10; Origene Technologies, Inc.) for $30 \mathrm{~min}$ at $37^{\circ} \mathrm{C}$. Nuclear staining was performed with hematoxylin.

Statistical analysis. Statistical analysis was performed using a statistical package (SPSS 19.0, SPSS Inc.). Data are expressed as the mean $\pm \mathrm{SD}$. Differences for all groups were analyzed by one-way analysis of variance with LSD-t test. The level of statistical significance chosen was $\mathrm{P}<0.05$.

\section{Results}

Characterization, multiple differentiation potential and transfection of GMSCs. The adherent GMSCs were observed 5-7 days after initiation of the primary culture and reached $80 \%$ confluence by the 14-21 day. Under the optical microscope, the primary GMSCs displayed a fibroblast-like spindle form (Fig. 2A). At $72 \mathrm{~h}$ post-transfection, strong expression of GFP could be observed under the fluorescence microscope, and stable GFP expression was obtained during the process of subculturing (Fig. 2B). The cell colonies were easily identified using crystal violet staining (Fig. 2C and D). After the GMSCs had been cultured in the adipogenic medium for 2 weeks, lipid-rich globules were confirmed by Oil Red O staining in cytoplasm of the differentiated cells (Fig. 2E). No positive cell was found in the control group (Fig. 2F). After the GMSCs were cultured in the osteogenic medium for 4 weeks, mineralized nodules were observed using Alizarin Red S staining (Fig. 2G), and no positive cell was found in the control group (Fig. 2H). Flow cytometric analysis exhibited that GMSCs were positive for MSC markers CD73, CD90, CD105 and STRO-1 and expression percentages were $>95 \%$. Additionally, GMSCs were negative for hematopoietic cell markers CD45 and CD31 and expression percentages were <2\% (Fig. 2I).

An experimental hyperlipidemia model with periodontitis in mice is successfully established by ligation in ApoE $E^{-/-}$mice. Serum lipid levels of the $\mathrm{ApoE}^{-/}$mice were significantly increased after the 4-week HFD. ApoE ${ }^{-/}$mice displayed an 11.69-fold increase in LDL levels and an 8.31-fold increase in TC levels compared to those of the C57BL/6J mice. Moreover, a 2.04-fold increase in serum HDL levels and a 1.89-fold increase in serum TG levels were found in the $\mathrm{ApoE}^{-/}$mice compared to those of the C57BL/6J mice (Table II). The results demonstrated that a hyperlipidemic model induced by diet was successfully constructed in the $\mathrm{ApoE}^{-/}$mice after the 4-week HFD. The distances from CEJ to ABC at 12 sites bilaterally of the isolated maxillary bones were measured and calculated together, which represented the overall 
Table I. Primer sequences for reverse transcription-quantitative PCR.

\begin{tabular}{|c|c|c|c|}
\hline Target genes & Primer & Sequence & Fragment length (bp) \\
\hline \multirow[t]{2}{*}{$G A P D H$} & Forward & 5'-ATGGGTGTGAACCACGAGA-3' & 229 \\
\hline & Reverse & 5'-CAGGGATGATGTTCTGGGCA-3' & \\
\hline \multirow[t]{2}{*}{$P P A R-\alpha$} & Forward & 5'-CCAGGCTTTGCAAACTTGGA-3' & 180 \\
\hline & Reverse & 5'-GATGTCACAGAACGGCTTCC-3' & \\
\hline \multirow[t]{2}{*}{$S R E B P-1 \mathrm{c}$} & Forward & 5'-CCCACCTCAAACCTGGATCT-3' & 229 \\
\hline & Reverse & 5'-AAGCAGCAAGATGTCCTCCT-3' & \\
\hline
\end{tabular}

PPAR $\alpha$, peroxisome proliferator-activated receptor $\alpha$; SREBP-1c, sterol regulatory element binding protein-1c; GAPDH, glyceraldehyde 3-phosphate dehydrogenase; bp, base pairs.
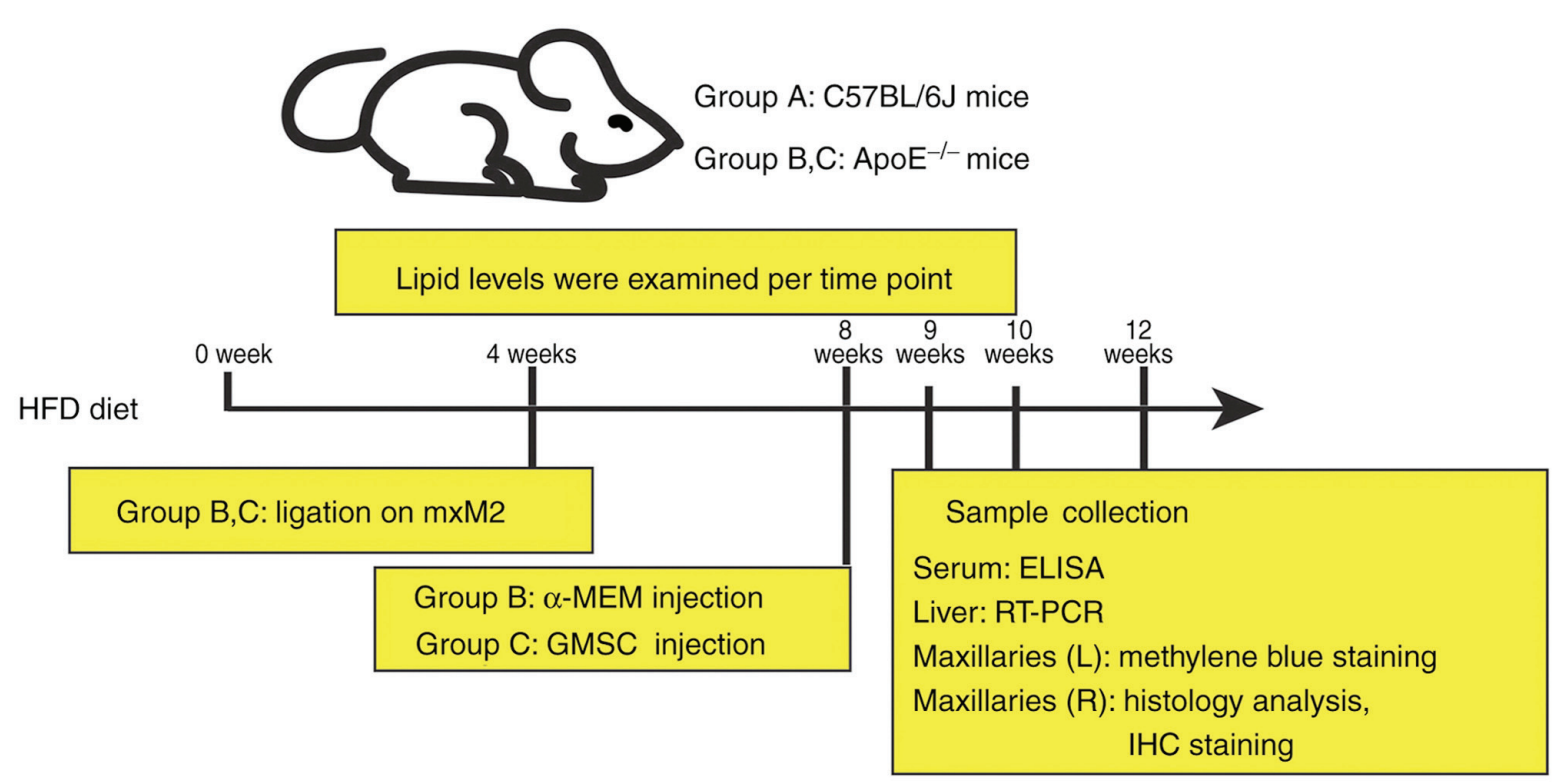

Figure 1. Diagram of the experimental design. Apolipoprotein E-deficient $\left(\mathrm{ApoE}^{-1}\right)$ mice were used to establish a hyperlipidemia model with periodontitis and were divided into two groups: Group B and Group C ( $\mathrm{n}=20$ per group), and wild-type C57BL/6J mice without any treatment were assigned to Group A ( $\mathrm{n}=20$ ). Animals in Group C were then injected with human GMSCs through the tail vein and animals in Group B were injected with $\alpha$-MEM as control. Animals were sacrificed at indicated time points. Serum were collected to determine lipids and inflammatory cytokines. Liver samples were collected to estimate lipid-associated gene expression. Morphometric and histological analyses were performed to maxillaries. IHC, immunohistochemistry; HFD, high fat diet; GMSCs, gingiva-derived mesenchymal stem cells.

alveolar bone resorption level. After a 4-week placement of ligatures, the alveolar bone resorption level of $\mathrm{ApoE}^{-/-}$mice was $4.76 \pm 0.55 \mathrm{~mm}$, which was significantly higher than that of the C57BL/6J mice with $1.99 \pm 0.25 \mathrm{~mm}(\mathrm{P}<0.05)$. This finding demonstrated that a periodontitis model was successfully constructed as alveolar bone resorption is an important pathological change of periodontitis. These results indicated that an experimental hyperlipidemia model with periodontitis was constructed in ApoE ${ }^{-/}$mice fed with a 4-week HFD and a 4-week placement of ligatures.

GMSCs attenuate serum lipid profiles. At week 8, 9, 10 and 12 , there was a significant increase in TG, TC, LDL and HDL levels in Group B and C compared to those in Group A $(\mathrm{P}<0.05)$. At week 9, 10 and 12, Group C exhibited a significant decrease in TG, TC, and LDL levels and a significant increase in HDL levels compared to those in Group B ( $\mathrm{P}<0.05$; Fig. 3$)$.
These results showed that GMSCs can attenuate serum lipid profiles.

GMSCs display anti-inflammatory functions. At week 8, 9, 10 and 12, the serum IL-6, IL-10 and TNF- $\alpha$ levels in Group B and C were significantly higher than those in Group A. At week 9, 10 and 12 , the serum IL- 6 and TNF- $\alpha$ (pro-inflammatory cytokines) levels in group $\mathrm{C}$ were significantly decreased compared to those in Group B, while the serum IL-10 (anti-inflammatory cytokine) level in Group $\mathrm{C}$ was significantly higher than that of Group B ( $\mathrm{P}<0.05$; Fig. 4). These results suggest that GMSCs display anti-inflammatory functions.

GMSCs affect expression of hepatic genes associated with lipid metabolism. At week 1, 2 and 4 after cell transplantation, levels of PPAR- $\alpha$ mRNA expression in the liver of Group C were significantly higher compared to that of Group B, while 
Table II. Comparison of the plasma lipid levels (mean $\pm \mathrm{SD}, \mathrm{mmol} / \mathrm{l}$ ) between ApoE ${ }^{-/}$mice and C57BL/6J mice at week 0 and 4 following the HFD $(n=6)$.

\begin{tabular}{|c|c|c|c|c|}
\hline \multirow[b]{2}{*}{ Plasma lipid levels } & \multicolumn{2}{|c|}{ C57BL/6J mice } & \multicolumn{2}{|c|}{$\mathrm{ApoE}^{-/-}$mice } \\
\hline & Week 0 & Week 4 & Week 0 & Week 4 \\
\hline TG & $0.82 \pm 0.21$ & $0.92 \pm 0.22$ & $1.18 \pm 0.21$ & $1.74 \pm 0.35^{\mathrm{a}}$ \\
\hline $\mathrm{TC}$ & $1.99 \pm 0.14$ & $3.65 \pm 0.52$ & $8.67 \pm 1.39$ & $30.33 \pm 7.71^{\mathrm{a}, \mathrm{b}}$ \\
\hline HDL & $1.51 \pm 0.17$ & $2.4 \pm 0.20$ & $2.54 \pm 0.47$ & $4.89 \pm 0.62^{\mathrm{a}, \mathrm{b}}$ \\
\hline LDL & $0.35 \pm 0.07$ & $0.84 \pm 0.16$ & $2.19 \pm 0.31$ & $9.82 \pm 3.03^{\mathrm{a}, \mathrm{b}}$ \\
\hline
\end{tabular}

${ }^{\mathrm{a}} \mathrm{P}<0.05$ vs. the $\mathrm{C} 57 \mathrm{BL} / 6 \mathrm{~J}$ mice (week 4); ${ }^{\mathrm{b}} \mathrm{P}<0.05$ vs. the $\mathrm{ApoE}{ }^{-/}$mice (week 0). TG, triglyceride; TC, total cholesterol; HDL, high density lipoprotein cholesterol; LDL, low density lipoprotein cholesterol.

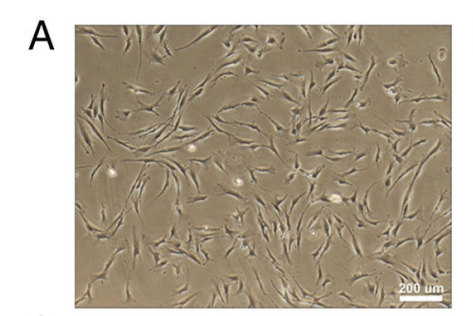

C
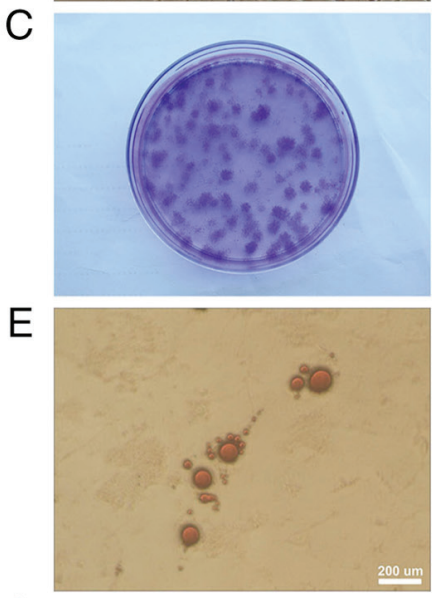

G

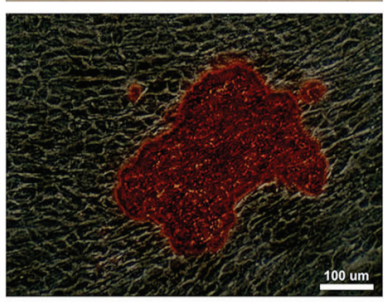

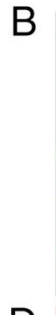

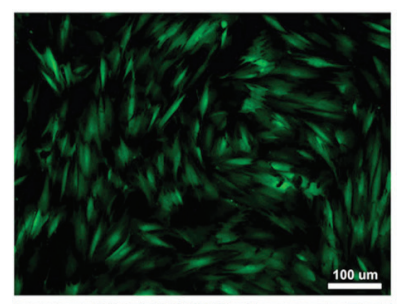

D

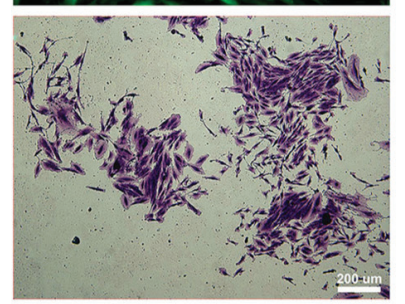

$\mathrm{F}$

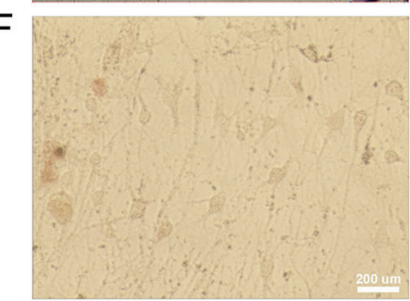

$\mathrm{H}$

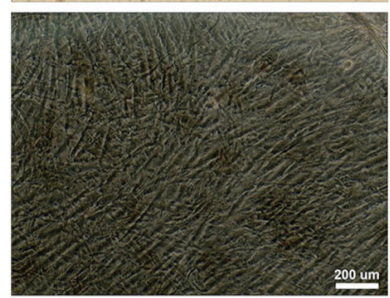

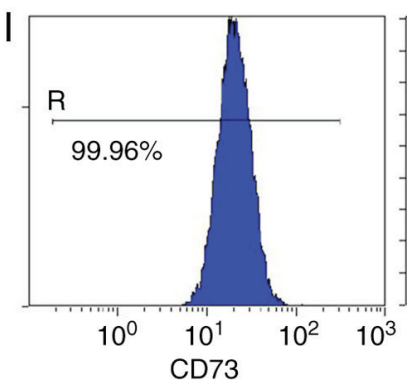
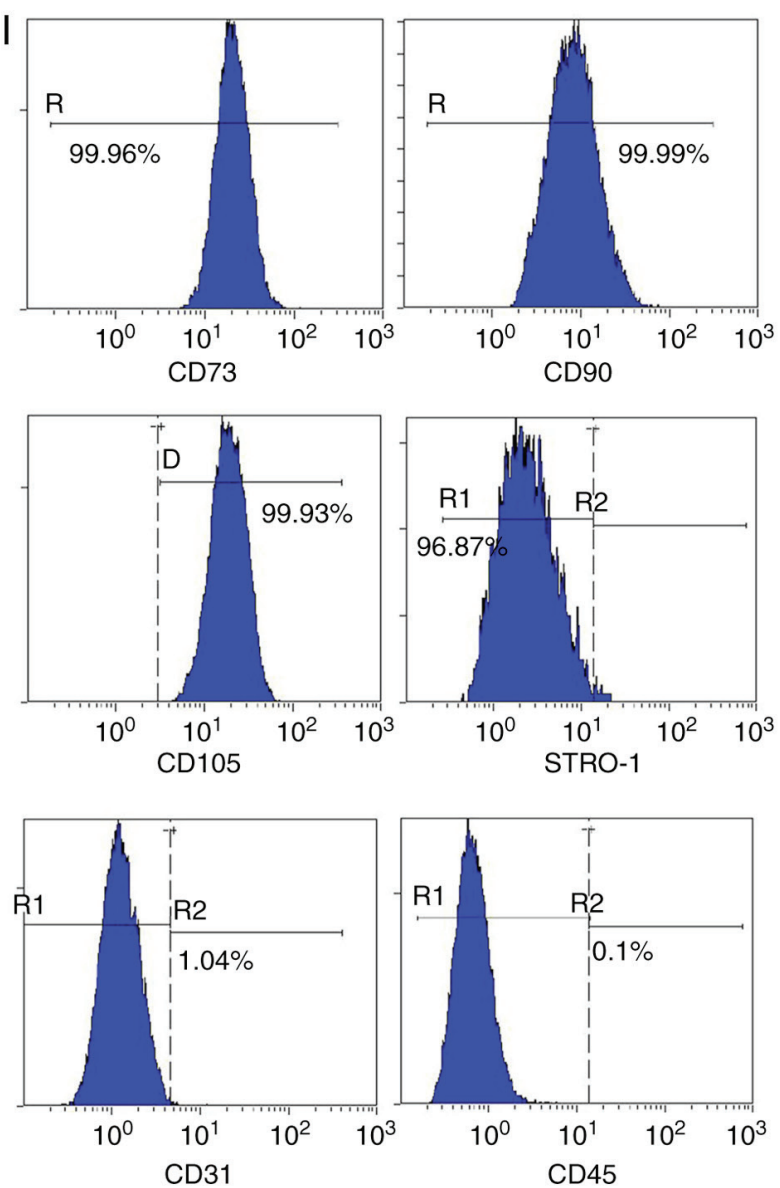

Figure 2. Traits of the GMSCs. (A) Morphology of primary GMSCs. (B) Expression of GFP in the transfected GMSCs. (C) CFU-F assay at day 14 and colonies were stained by $1 \%$ crystal violet. (D) Cell colonies formed in the CFU-F assay. (E) Lipid droplets were observed in cells cultured under adipogenic condition for 2 weeks after Oil Red O staining. (F) Lipid droplets were not detected in the control group. (G) Mineralized nodules were observed in cells cultured under osteogenic condition for 4 weeks after Alizarin Red S staining. (H) Mineralized nodules were not detected in the control group. (I) Flow cytometric analysis demonstrated that GMSCs were positive for CD73, CD90, CD105 and STRO-1 and negative for CD31 and CD45. GMSCs, gingiva-derived mesenchymal stem cells; GFP, green fluorescent protein.

the levels of SREBP-1c mRNA were significantly reduced $(\mathrm{P}<0.05$; Fig. 5A and $\mathrm{B})$. These results indicate that GMSCs affect expression of hepatic genes associated with lipid metabolism.

GMSCs promote alveolar bone regeneration. Alveolar bone loss was determined as the distance from $\mathrm{ABC}$ to $\mathrm{CEJ}$
(Fig. 5C). At week 1 and 2 post-transplantation, there were insignificant differences between Group B and C. However, alveolar bone loss in Group $\mathrm{C}$ was significantly less than that of Group B and no significant difference was detected between Group A and C at the 4th week, which indicated the promotion of alveolar bone regeneration by systemically transplanted GMSCs (P<0.05; Fig. 5D). 

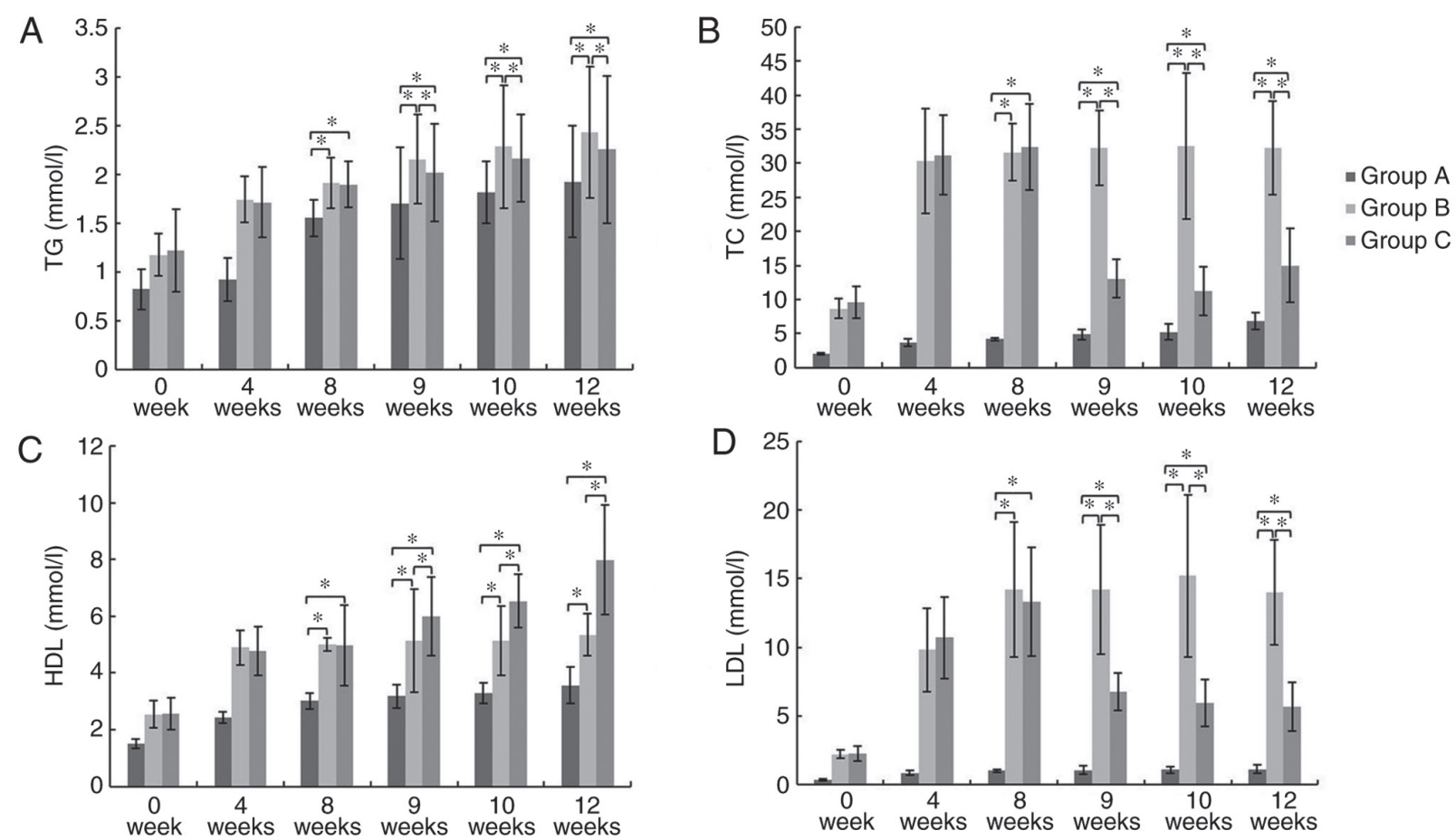

Figure 3. Serum lipid levels. (A) TG, (B) TC, (C), HDL and (D) LDL. "P<0.05. At week 9, 10, and 12, Group C exhibited a significant decrease in TG, TC, and LDL levels and a significant increase in HDL levels compared to those in Group B. TG, triglyceride; TC, total cholesterol; HDL, high density lipoprotein cholesterol; LDL, low density lipoprotein cholesterol.
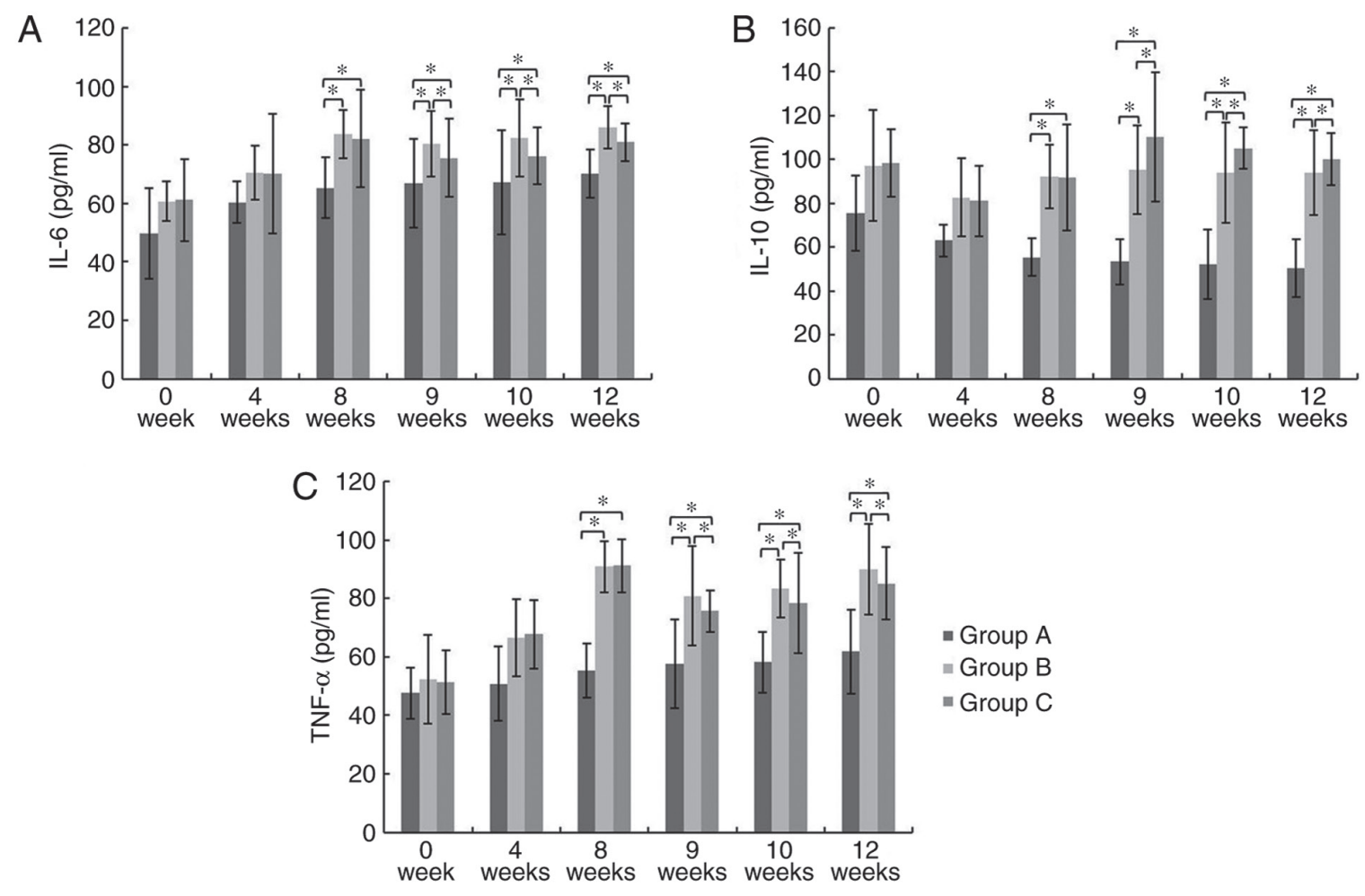

Figure 4. Serum IL-6, IL-10, and TNF- $\alpha$ levels. (A) IL-6, (B) IL-10 and (C) TNF- $\alpha$. "P<0.05. At week 9,10 and 12, the serum IL-6 and TNF- $\alpha$ (pro-inflammatory cytokines) levels in Group C were significantly decreased than those in Group B, while the serum IL-10 (anti-inflammatory cytokine) level in Group C was significantly higher than that of Group B. IL, interleukin; TNF- $\alpha$, tumor necrosis factor $\alpha$

GMSCs improve the pathologic features of periodontitis. Histological changes in the interradicular region were observed by H\&E and MT staining. At week 1 and 2 after transplantation, deep periodontal pockets, attachment loss, inflammatory cell infiltration, and severe alveolar bone destruction were detected in Group B and Group C by H\&E staining. 

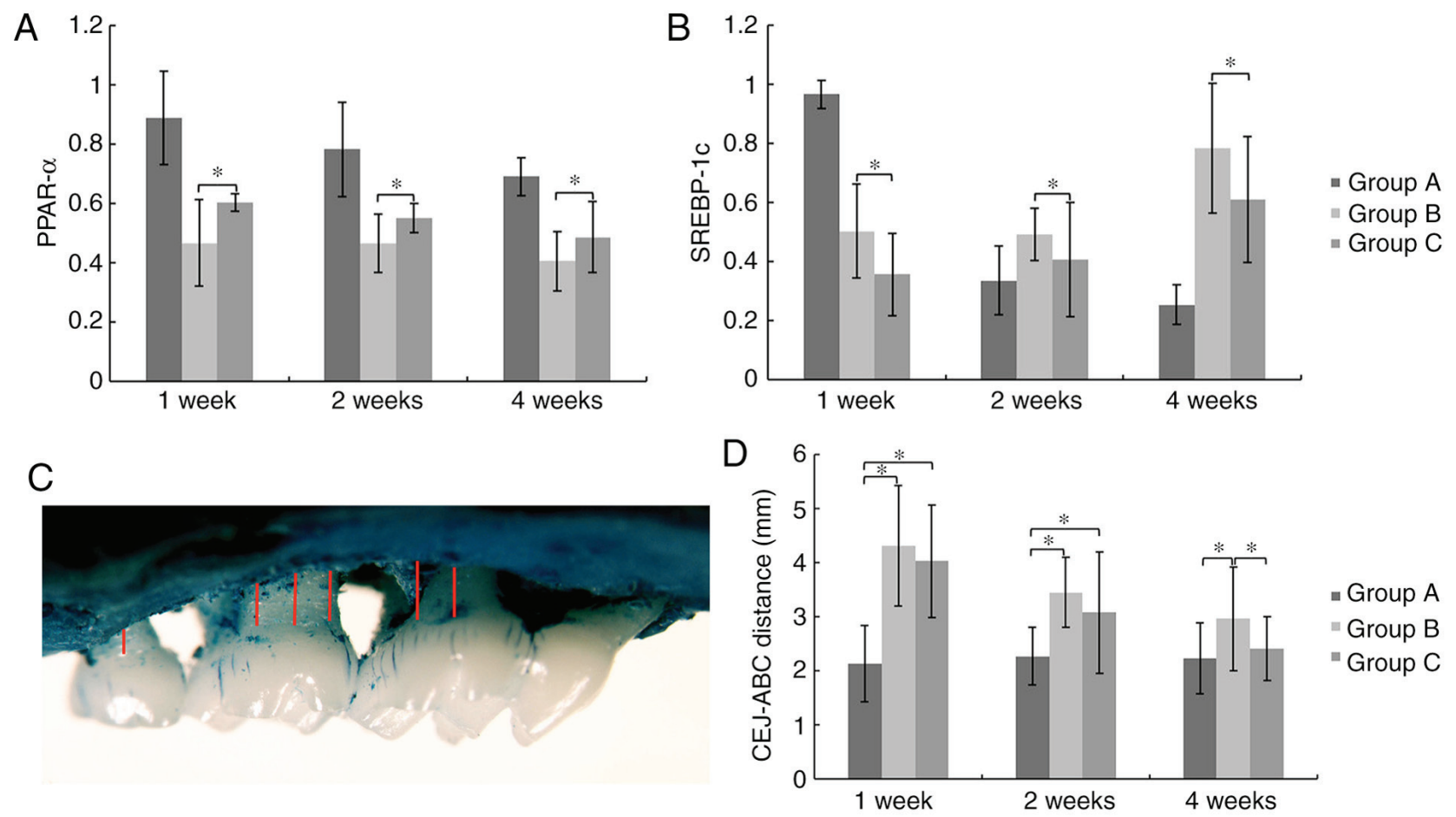

Figure 5. mRNA levels of PPAR $\alpha$ and SREBP-1c in the liver and alveolar bone loss caused by periodontitis. (A) PPAR $\alpha$. (B) SREBP-1c. "P<0.05. At week 1, 2 and 4 after cell transplantation, PPAR- $\alpha$ mRNA expression in the liver of Group C was significantly higher compared to that of Group B, while the levels of SREBP-1c mRNA were significantly reduced. (C) Measurements were performed on 6 sites at the palatal or buccal side. (D) The distances from CEJ to $\mathrm{ABC}$ at 12 sites bilaterally were measured and calculated together (mean $\pm \mathrm{SD}, \mathrm{mm}$ ). $\mathrm{P}<0.05$. Alveolar bone loss in Group $\mathrm{C}$ was significantly less than that of Group B at week 4 post transplantation. PPAR $\alpha$, peroxisome proliferator-activated receptor $\alpha$; SREBP-1c, sterol regulatory element binding protein-1c; CEJ, cementoenamel junction; $\mathrm{ABC}$, alveolar bone crest.

At week 4 post-transplantation, less periodontal pocket depth, attachment loss and inflammatory cell infiltration and higher alveolar bone heights were observed in Group C compared to those of Group B, which were consistent with the methylene blue staining results (Fig. 6A). Additionally, MT staining indicated that almost all of the alveolar bones were stained blue and there were more reddish stained mature bones in Group C than in Group B at week 4 (Fig. 6B). These results showed that GMSCs can improve the pathologic features of periodontitis and promote alveolar bone regeneration.

GMSCs home to periodontal injury sites. GFP-positive $\left(\mathrm{GFP}^{+}\right)$cells were detected in both fluorescence microscope observation and immunohistochemical staining. At week 1 post-transplantation, $\mathrm{GFP}^{+}$fibroblast-like cells were detected in the periodontal ligament. At week 2 post-transplantation, $\mathrm{GFP}^{+}$fibroblast-like cells were found in the periodontal ligament and $\mathrm{GFP}^{+}$osteoblasts were detected close to the alveolar bone. Furthermore, $\mathrm{GFP}^{+}$osteoblasts were identified in the area of newly formed alveolar bone at week 4 post-transplantation. These results revealed that GMSCs can home to periodontal injury sites and promote tissue regeneration (Fig. 7A and B).

\section{Discussion}

Stem cell-based therapy has been considered to be a hopeful alternative for regenerative medicine, but various drawbacks and limitations hinder the popularization and application of these mesenchymal stem cells (MSCs). Bone marrow has been regarded as the best source of MSCs despite various sources to date. However, bone marrow is a limited source and a large amount of pain is caused to the patient when samples are harvested (26-28). By comparison, the source of gingiva-derived mesenchymal stem cells (GMSCs) is discarded gingiva tissue from patients undergoing tooth extraction or periodontal surgery. In addition, it is reported that most of the biological properties of GMSCs are superior to those of bone marrow-derived mesenchymal stem cells (BMSCs) (23).

To confirm our assumption that GMSCs possess the abilities of lipid metabolism regulation and anti-inflammation, we isolated GMSCs from gingival tissue, where the harvested cells displayed self-renewal capabilities and multilineage differentiation potential toward the adipogenic and osteogenic conditions in vitro when GMSCs were cultured with built lineage-specific differentiation factors. This was in conformity with previous findings $(23,29)$. Moreover, the results of flow cytometric analysis showed that GMSCs express the MSC markers CD73, CD90, CD105 and STRO-1, but lack the hematopoietic stem marker CD45 and endothelial cell marker CD31. These results were consistent with the criteria for mesenchymal stromal cells suggested by the International Society for Cellular Therapy (26). As the integration and expression of GFP genes in MSCs have no significant effect on stem cell traits (30), we transduced the GFP gene into GMSCs using lentiviral vectors to trace the fate of GMSCs in vivo.

In the 1990s, $\mathrm{ApoE}^{-/}$mouse models were developed by two independent research groups, and both groups reported that ApoE gene deficiency resulted in severe hyperlipidemia and 
A
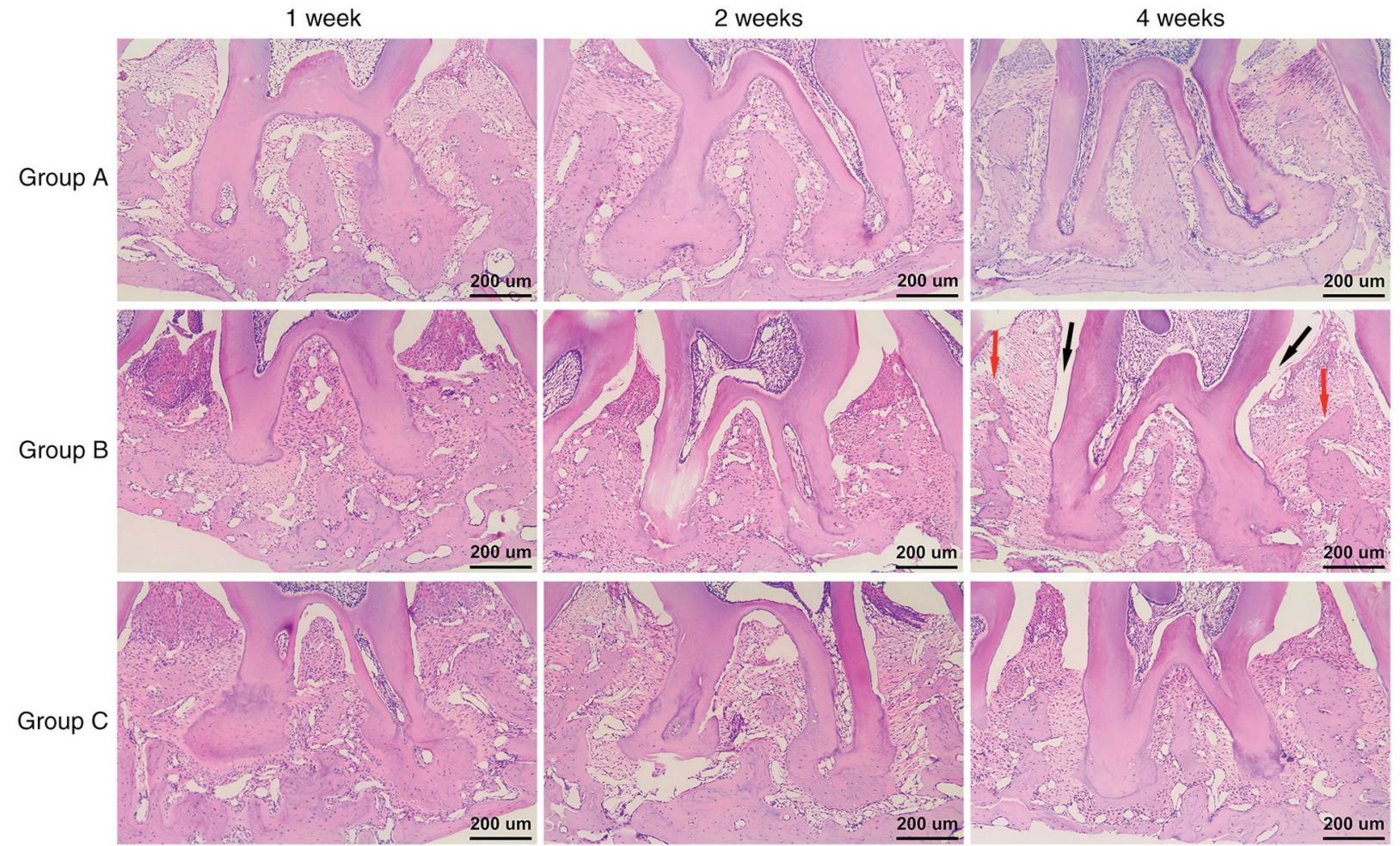

B

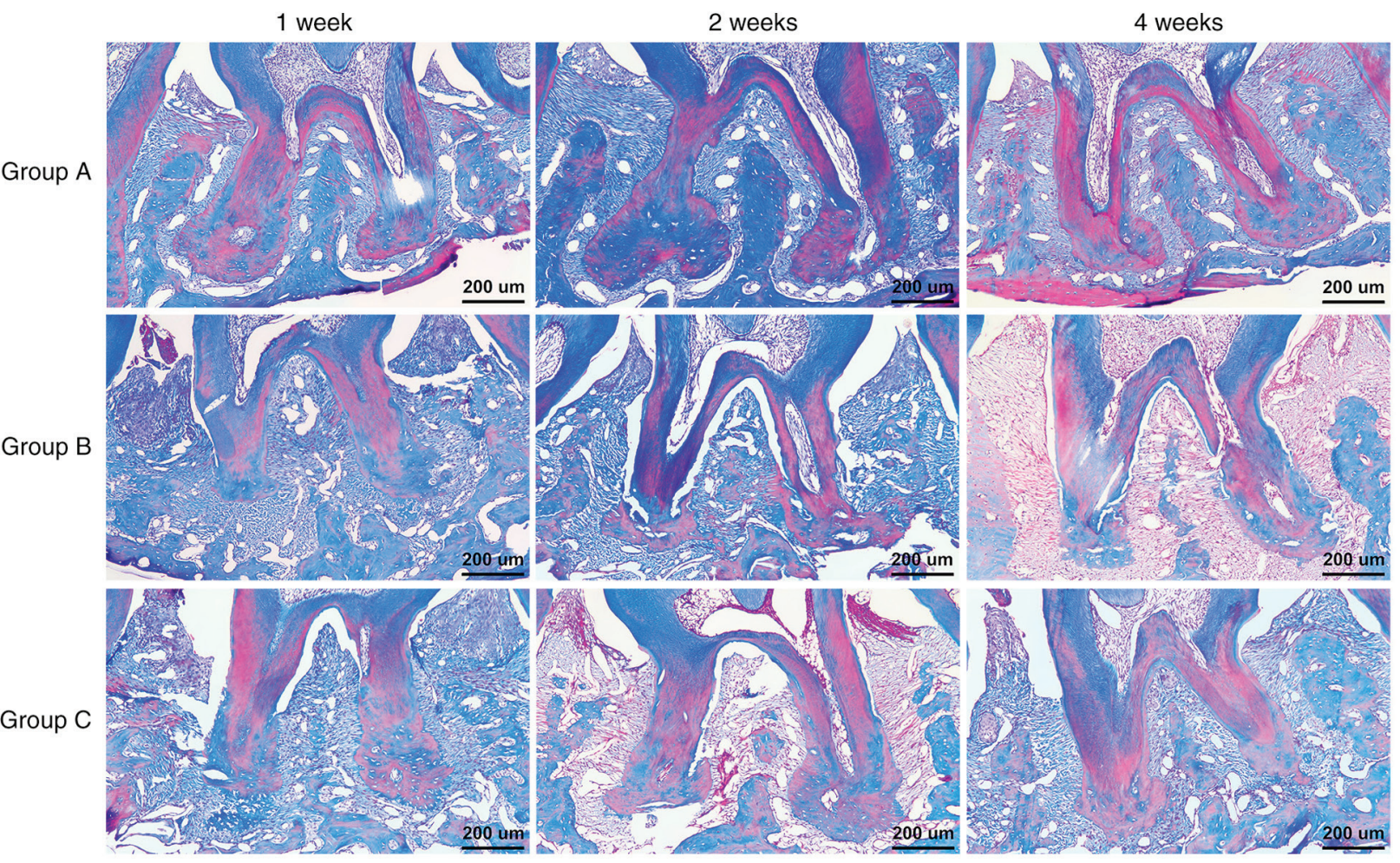

Figure 6. Histopathological changes at interradicular region and $\mathrm{GFP}^{+}$cells in periodontal tissue. (A) Observation under x100 magnification by H\&E staining. At week 4 post-transplantation, less periodontal pocket (indicated by black arrowheads) depth, attachment loss and inflammatory cell infiltration and higher alveolar bone (indicated by red arrowheads) heights were observed in Group C compared to those of Group B. (B) Observation under x100 magnification by MT staining. Almost all of the alveolar bones were stained blue and there were more reddish stained mature bones in Group C than in Group B at week 4. GFP, green fluorescent protein; H\&E, hematoxylin and eosin.

spontaneous atherosclerotic lesions $(31,32)$. In our research, a hyperlipidemia model was constructed using $\mathrm{ApoE}^{-/-}$mice that were fed a high fat diet (HFD). Our findings exhibited that $\mathrm{ApoE}^{-/-}$mice displayed dramatic increases in serum total cholesterol (TC) and low density lipoprotein cholesterol (LDL) levels when compared to those in the $\mathrm{C} 57 \mathrm{BL} / 6 \mathrm{~J}$ mice after a 4-week HFD. In effect, the existence of ligatures disturbed periodontal homeostasis via accelerating local accumulation of bacteria (24). After 4 weeks of ligatures, we observed obvious alveolar bone loss in the $\mathrm{ApoE}^{-/-}$mice, which indicated that 
A

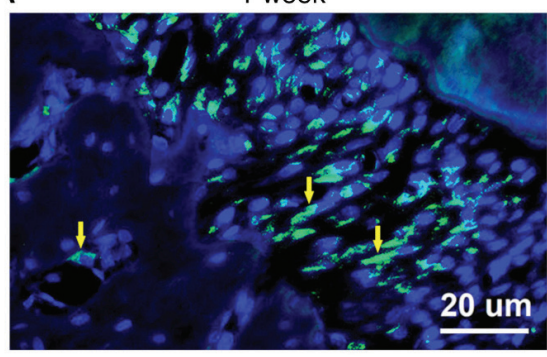

B

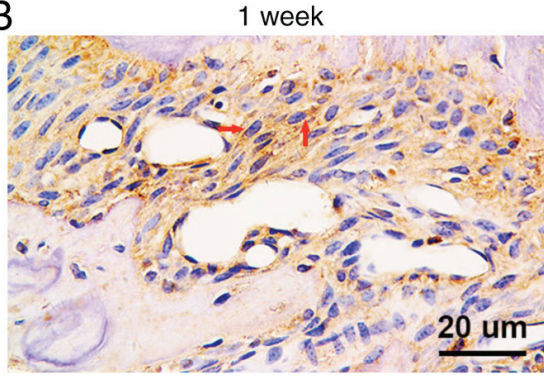

2 weeks

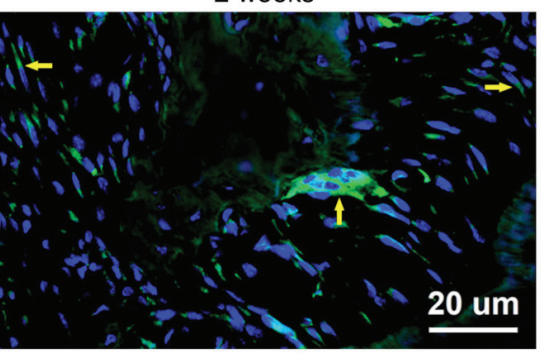

2 weeks

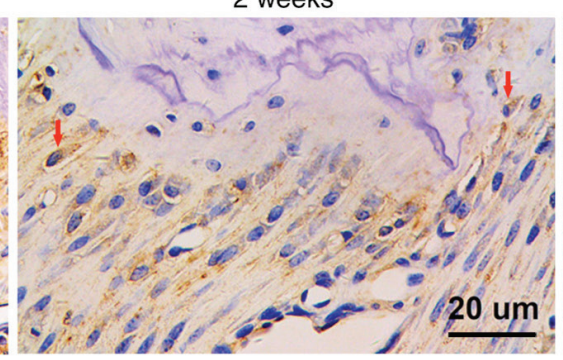

4 weeks

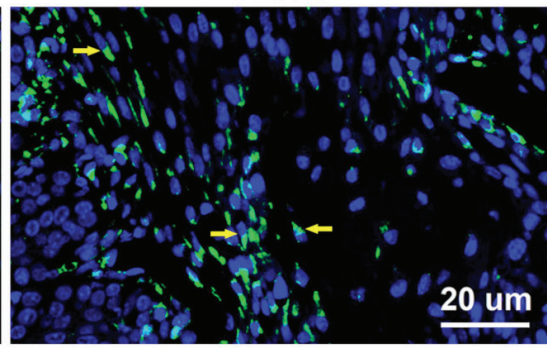

4 weeks

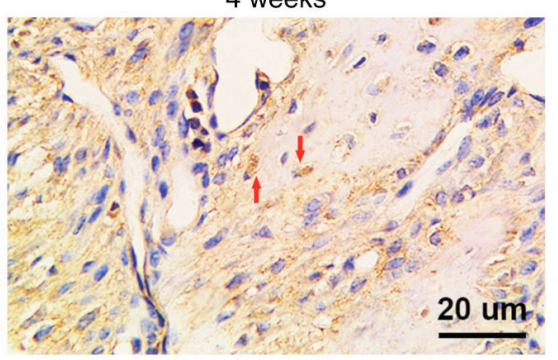

Figure 7. (A) Observation under fluorescence microscopy. Cells contained green cytoplasm and blue stained nuclei were observed (indicated by yellow arrowheads) under x400 magnification. (B) Anti-GFP immunohistochemical staining. GFP ${ }^{+}$gingival fibroblasts, periodontal ligament cells and osteoblasts were observed (indicated by red arrowheads) under x400 magnification. GFP, green fluorescent protein.

periodontitis was established. Most of the previous studies constructed the animal model of periodontitis using a silk ligature soaked with live Porphyromonas gingivalis suspension $(33,34)$, however our ligation method without bacteria was more economical.

Group C showed a significant increase in HDL levels and a significant reduction in TC, triglycerides (TG) and LDL levels when compared to those of Group B post-transplantation, which were in line with former findings confirming that MSCs have the capacity to attenuate serum lipid profiles and oxidative stress (19). MSCs derived from induced pluripotent stem cells were found to restore cigarette smoke-induced cardiac dysfunction through regulation of fatty acid, triglyceride and cholesterol metabolism, which led to alleviation of cardiac inflammation and oxidative stress in a rat model of passive smoking (35). Adipose-derived mesenchymal stem cell infusion was found to significantly repress the growth in body weight and dramatically improve serum lipid profiles (TG, TC, LDL) in diet-induced obese mice and $\mathrm{db} / \mathrm{db}$ mice respectively as obesity and hyperlipidemia models (36). A significant $33 \%$ reduction in serum TC levels in BMSC-treated mice was found after 8 weeks of a Western-type diet (37).

Similar to BMSCs, GMSCs display powerful immunomodulatory impacts on innate immune cells, particularly macrophages, dendritic cells (DCs) and mast cells (MCs) (14,38-40). In a mouse model of skin wound healing, treatment using GMSCs exhibited a dynamic downregulation in the expression of M1-cytokines (IL-6 and TNF- $\alpha$ ) and an upregulation in the amount of M2 macrophages and the level of anti-inflammatory cytokine IL-10. This then mitigated local inflammation and significantly enhanced wound repair during the wound healing process (40). Through a $\mathrm{PGE}_{2}$-mediated activation of the system E prostanoid (EP) receptor/cAMP/protein-kinase-A (PKA) which created a docking site for the initiation of IL-10 transactivation, GMSCs significantly repressed the maturation and activation of DCs, reducing their antigen presentation capacity and ameliorating the inflammatory response (14). GMSCs have been shown to exhibit a suppressive effect on the acquired immune system via an increase in IL-10 and decrease in tryptophan secretion in a cell-cell contact dependent and independent manner, to repress PHA-dependent T-lymphocyte proliferation and activation $(13,21)$. The present study showed a downregulation in serum pro-inflammatory cytokine (TNF- $\alpha$ and IL-6) levels and an upregulation in serum anti-inflammatory cytokine (IL-10) level after GMSC transplantation, which are in line with previous research studies that have confirmed that GMSCs display marked immunomodulatory properties.

In a previous study, BMSCs displayed significant upregulation of the PPAR- $\alpha$ pathway and downregulation of fatty acid biosynthesis when systematically transplanted 7 days before renal ischemia/reperfusion in rats (41). Nevertheless, a recent study using a rat model indicated that systematically transplanted BMSCs in radiation-induced heart injury decreased the expression of PPAR- $\alpha$ (42). In the present study, PPAR- $\alpha$ mRNA expression in the liver of Group $C$ was significantly higher compared to that of Group B at week 1,2 and 4 after transplantation. Furthermore, the infusion of MSCs activated the PPAR- $\alpha$ pathway. PPAR- $\alpha$ controls the expression of several types of hepatic genes encoding for enzymes/proteins involved in fatty acid metabolism (uptake, intracellular transport, activation and oxidation), lipogenesis, ketogenesis and lipoprotein/cholesterol metabolism. Numerous studies have shown that PPAR- $\alpha$ plays a key role in hepatic lipoprotein and fatty acid metabolism $(43,44)$. Liver mRNA expression of SREBP-1c had an 18\% reduction in BMSC-treated atherosclerosis mice (37). However, transplantation of BMSCs had no effect on SREBP-1c mRNA expression in diet-induced obese mice (45). Our results displayed that SREBP-1c mRNA expression in the liver of Group $\mathrm{C}$ was significantly decreased 
compared to that of Group B at week 1, 2 and 4 after transplantation of GMSCs. SREBP-1c induces the expression of a family of genes which have an effect on fatty acid synthesis and glucose utilization (46).

In this study, alveolar bone loss in Group B was significantly greater than that of Group $\mathrm{C}$ at week 4 post transplantation, which indicated promotion of systemically transplanted GMSCs on alveolar bone regeneration. Results of H\&E and MT staining showed more newly formed bone and higher alveolar bone heights in Group C compared with those of Group B at week 4 post-transplantation. $\mathrm{GFP}^{+}$gingival fibroblasts, periodontal ligament cells and osteoblasts were detected after transplantation. These results forcefully supported our hypothesis that systemically transplanted GMSCs can home to periodontitis sites and differentiate into periodontal tissue cells.

Overall, the findings of the present study showed that systematically transplanted GMSCs regulate lipid metabolism and inflammation in hyperlipidemic mice with periodontitis. Further studies are needed to clarify the cellular and molecular mechanisms underlying the improvement of hyperlipidemia and inflammatory responses. The present study provides a novel strategy with which to clinically treat periodontitis patients with hyperlipidemia and other systemic diseases and offers experimental evidence for application of GMSCs in cell replacement therapy.

\section{Acknowledgements}

Not applicable.

\section{Funding}

This work was supported by Shandong Province Key Research Plan (grant no. 2018GSF118150) to QX and Shandong Provincial National Science Foundation (grant no. ZR2017MH083) to ZW.

\section{Availability of data and materials}

The datasets used and/or analyzed during the current study are available from the corresponding author on reasonable request.

\section{Authors' contributions}

All authors aided in the proposal of the research idea and participated in the design of the experiments. XL performed the animal experiments and wrote the manuscript. ZW and WBS collected and analyzed the data. WDS and RH performed the cell experiment. AP and QX interpreted the data and critically revised the manuscript. All authors read and approved the manuscript and agree to be accountable for all aspects of the research in ensuring that the accuracy or integrity of any part of the work are appropriately investigated and resolved.

\section{Ethics approval and consent to participate}

All procedures performed in studies involving animals were approved by the Institutional Review Board and The Ethics Committee of The Affiliated Hospital of Qingdao University (approval no. QYFYKYLL-2017-01-2).

\section{Patient consent for publication}

Not applicable.

\section{Competing interests}

The authors declare that they have no competing interests.

\section{References}

1. 1999 International International Workshop for a Classification of Periodontal Diseases and Conditions. Papers. Oak Brook, illinois, October 30-November 2, 1999. Ann Periodontol 4: i, 1-112, 1999.

2. Jain N, Jain GK, Javed S, Iqbal Z, Talegaonkar S, Ahmad FJ and Khar RK: Recent approaches for the treatment of periodontitis. Drug Discov Today 13: 932-943, 2008.

3. Nelson RH: Hyperlipidemia as a risk factor for cardiovascular disease. Prim Care 40: 195-211, 2013.

4. Awartani F and Atassi F: Evaluation of periodontal status in subjects with hyperlipidemia. J Contemp Dent Pract 11: 033-040, 2010.

5. Sangwan A, Tewari S, Singh H, Sharma RK and Narula SC: Periodontal status and hyperlipidemia: Statin users versus non-users. J Periodontol 84: 3-12, 2013.

6. Sandi RM, Pol KG, Basavaraj P, Khuller N and Singh S: Association of serum cholesterol, triglyceride, high and low density lipoprotein (HDL and LDL) levels in chronic periodontitis subjects with risk for cardiovascular disease (CVD): A cross sectional study. J Clin Diagn Res 8: 214-216, 2014.

7. D'Aiuto F, Nibali L, Parkar M, Suvan J and Tonetti MS: Short-term effects of intensive periodontal therapy on serum inflammatory markers and cholesterol. J Dent Res 84: 269-273, 2005.

8. Maglakelidze N, Galogre A and Tsagareli Z: Functional-morphologic aspects of changes of mucosal gingiva microcirculatory bed vessels in experimental gingivitis against the background of hypercholesterolemia. Georgian Med News 121: 71-74, 2005 (In Russian).

9. Li L, Messas E, Batista EL Jr, Levine RA and Amar S: Porphyromonas gingivalis infection accelerates the progression of atherosclerosis in a heterozygous apolipoprotein E-deficient murine model. Circulation 105: 861-867, 2002.

10. Buhlin K, Gustafsson A, Pockley AG, Frostegård J and Klinge B: Risk factors for cardiovascular disease in patients with periodontitis. Eur Heart J 24: 2099-2107, 2003.

11. Seijkens T, Hoeksema MA, Beckers L, Smeets E, Meiler S, Levels J, Tjwa M, de Winther MP and Lutgens E: Hypercholesterolemia-induced priming of hematopoietic stem and progenitor cells aggravates atherosclerosis. FASEB J 28: 2202-2213, 2014

12. Fentoğlu Ö, Kırzıoğlu FY, Bulut MT, Kumbul Doğuç D, Kulaç E, Önder $C$ and Günhan M: Evaluation of lipid peroxidation and oxidative DNA damage in patients with periodontitis and hyperlipidemia. J Periodontol 86: 682-688, 2015.

13. Zhang Q, Shi S, Liu Y, Uyanne J, Shi Y, Shi S and Le AD: Mesenchymal stem cells derived from human gingiva are capable of immunomodulatory functions and ameliorate inflammation-related tissue destruction in experimental colitis. J Immunol 183: 7787-7798, 2009.

14. Su WR, Zhang QZ, Shi SH, Nguyen AL and Le AD: Human gingiva-derived mesenchymal stromal cells attenuate contact hypersensitivity via prostaglandin E2-dependent mechanisms. Stem Cells 29: 1849-1860, 2011.

15. Wada N, Wang B, Lin NH, Laslett AL, Gronthos S and Bartold PM: Induced pluripotent stem cell lines derived from human gingival fibroblasts and periodontal ligament fibroblasts. J Periodontal Res 46: 438-447, 2011.

16. Yu X, Ge S, Chen S, Xu Q, Zhang J, Guo H and Yang P: Human gingiva-derived mesenchymal stromal cells contribute to periodontal regeneration in beagle dogs. Cells Tissues Organs 198: 428-437, 2013.

17. Xu QC, Wang ZG, Ji QX, Yu XB, Xu XY, Yuan CQ, Deng J and Yang PS: Systemically transplanted human gingiva-derived mesenchymal stem cells contributing to bone tissue regeneration. Int J Clin Exp Pathol 7: 4922-4929, 2014.

18. Xu X, Chen C, Akiyama K, Chai Y, Le AD, Wang Z and Shi S: Gingivae contain neural-crest- and mesoderm-derived mesenchymal stem cells. J Dent Res 92: 825-832, 2013. 
19. EI-Tantawy WH and Haleem EN: Therapeutic effects of stem cell on hyperglycemia, hyperlipidemia, and oxidative stress in alloxan-treated rats. Mol Cell Biochem 391: 193-200, 2014

20. Tang L, Li N, Xie H and Jin Y: Characterization of mesenchymal stem cells from human normal and hyperplastic gingiva. J Cell Physiol 226: 832-842, 2011.

21. Zhang QZ, Nguyen AL, Yu WH and Le AD: Human oral mucosa and gingiva: A unique reservoir for mesenchymal stem cells. J Dent Res 91: 1011-1018, 2012.

22. Xu QC, Hao PJ, Yu XB, Chen SL, Yu MJ, Zhang J and Yang PS: Hyperlipidemia compromises homing efficiency of systemically transplanted BMSCs and inhibits bone regeneration. Int J Clin Exp Pathol 7: 1580-1587, 2014

23. Tomar GB, Srivastava RK, Gupta N, Barhanpurkar AP, Pote ST, Jhaveri HM, Mishra GC and Wani MR: Human gingiva-derived mesenchymal stem cells are superior to bone marrow-derived mesenchymal stem cells for cell therapy in regenerative medicine. Biochem Biophys Res Commun 393: 377-383, 2010.

24. Abe T and Hajishengallis G: Optimization of the ligature-induced periodontitis model in mice. J Immunol Methods 394: 49-54, 2013.

25. Livak KJ and Schmittgen TD: Analysis of relative gene expression data using real-time quantitative PCR and the 2(-Delta Delta C(T)) method. Methods 25: 402-408, 2001

26. Dominici M, Le Blanc K, Mueller I, Slaper-Cortenbach I, Marini F, Krause D, Deans R, Keating A, Prockop Dj and Horwitz E: Minimal criteria for defining multipotent mesenchymal stromal cells. The international society for cellular therapy position statement. Cytotherapy 8: 315-317, 2006.

27. Chamberlain G, Fox J, Ashton B and Middleton J: Concise review: Mesenchymal stem cells: Their phenotype, differentiation capacity, immunological features, and potential for homing. Stem Cells 25: 2739-2749, 2007.

28. Ren G, Zhang L, Zhao X, Xu G, Zhang Y, Roberts AI, Zhao RC and Shi Y: Mesenchymal stem cell-mediated immunosuppression occurs via concerted action of chemokines and nitric oxide. Cell Stem Cell 2: 141-150, 2008.

29. Wang F, Yu M, Yan X, Wen Y, Zeng Q, Yue W, Yang P and Pei X: Gingiva-derived mesenchymal stem cell-mediated therapeutic approach for bone tissue regeneration. Stem Cells Dev 20: 2093-2102, 2011.

30. Ye Z, Yu X and Cheng L: Lentiviral gene transduction of mouse and human stem cells. Methods Mol Biol 430: 243-253, 2008.

31. Plump AS, Smith JD, Hayek T, Aalto-Setälä K, Walsh A, Verstuyft JG, Rubin EM and Breslow JL: Severe hypercholesterolemia and atherosclerosis in apolipoprotein E-deficient mice created by homologous recombination in ES cells. Cell 71: 343-353, 1992.

32. Zhang SH, Reddick RL, Piedrahita JA and Maeda N: Spontaneous hypercholesterolemia and arterial lesions in mice lacking apolipoprotein E. Science 258: 468-471, 1992.

33. Meulman T, Peruzzo DC, Stipp RN, Goncalves PF, Sallum EA, Casati MZ, Goncalves RB and Nociti FH Jr: Impact of Porphyromonas gingivalis inoculation on ligature-induced alveolar bone loss. A pilot study in rats. J Periodontal Res 46: 629-636, 2011.
34. Lin J, Bi L, Yu X, Kawai T, Taubman MA, Shen B and Han X: Porphyromonas gingivalis exacerbates ligature-induced, RANKL-dependent alveolar bone resorption via differential regulation of Toll-like receptor 2 (TLR2) and TLR4. Infect Immun 82: 4127-4134, 2014.

35. Liang Y, Li X, Zhang Y, Yeung SC, Zhen Z, Ip MSM, Tse HF, Lian Q and Mak JCW: Induced pluripotent stem cells-derived mesenchymal stem cells attenuate cigarette smoke-induced cardiac remodeling and dysfunction. Front Pharmacol 8: 501, 2017.

36. Liu GY, Liu J, Wang YL, Liu Y, Shao Y, Han Y, Qin YR, Xiao FJ, Li PF, Zhao LJ, et al: Adipose-derived mesenchymal stem cells ameliorate lipid metabolic disturbance in mice. Stem Cells Transl Med 5: 1162-1170, 2016.

37. Frodermann V, van Duijn J, van Pel M, van Santbrink PJ, Bot I, Kuiper J and de Jager SC: Mesenchymal stem cells reduce murine atherosclerosis development. Sci Rep 5: 15559, 2015.

38. English K and Mahon BP: Allogeneic mesenchymal stem cells: Agents of immune modulation. J Cell Biochem 112: 1963-1968, 2011.

39. Lee RH, Oh JY, Choi H and Bazhanov N: Therapeutic factors secreted by mesenchymal stromal cells and tissue repair. J Cell Biochem 112: 3073-3078, 2011.

40. Zhang QZ, Su WR, Shi SH, Wilder-Smith P, Xiang AP, Wong A Nguyen AL, Kwon CW and Le AD: Human gingiva-derived mesenchymal stem cells elicit polarization of $\mathrm{m} 2$ macrophages and enhance cutaneous wound healing. Stem Cells 28: 1856-1868, 2010.

41. Erpicum P, Rowart P, Poma L, Krzesinski JM, Detry O and Jouret F: Administration of mesenchymal stromal cells before renal ischemia/reperfusion attenuates kidney injury and may modulate renal lipid metabolism in rats. Sci Rep 7: 8687, 2017.

42. Gao S, Zhao Z, Wu R, Zeng Y, Zhang Z, Miao J and Yuan Z: Bone marrow mesenchymal stem cell transplantation improves radiation-induced heart injury through DNA damage repair in rat model. Radiat Environ Biophys 56: 63-77, 2017.

43. Pyper SR, Viswakarma N, Yu S and Reddy JK: PPARalpha: Energy combustion, hypolipidemia, inflammation and cancer. Nucl Recept Signal 8: e002, 2010.

44. Rakhshandehroo M, Knoch B, Müller M and Kersten S: Peroxisome proliferator-activated receptor alpha target genes. PPAR Res 2010: 612089, 2010.

45. Lin YY, Chen CY, Lin Y, Chiu YP, Chen CC, Liu BH, Mersmann HJ, Wu SC and Ding ST: Modulation of glucose and lipid metabolism by porcine adiponectin receptor 1-transgenic mesenchymal stromal cells in diet-induced obese mice. Cytotherapy 15: 971-978, 2013.

46. Ferré $\mathrm{P}$ and Foufelle F: SREBP-1c transcription factor and lipid homeostasis: Clinical perspective. Horm Res 68: 72-82, 2007.

(i) $\Theta$ This work is licensed under a Creative Commons Attribution-NonCommercial-NoDerivatives 4.0 International (CC BY-NC-ND 4.0) License. 